\title{
PARA UMA HISTÓRIA PLEBEIA DO LIBERALISMO
}

\author{
Ian Merkel*
}

New York University

Nova lorque - Nova lorque - Estados Unidos

Resenha do livro: SARTORI, Andrew. Liberalism in Empire: An Alternative History.

Oakland: California University Press, 2014.

Neste último livro de Andrew Sartori, o autor trata da questão do "liberalismo plebeu" de uma maneira que promete mudar a direção da historiografia. Os discursos e a ideologia liberais foram considerados, até recentemente, como produtos da elite. Nesse sentido, a ideia do contrato social de Locke, por exemplo, protegia a propriedade destas mesmas elites. Sartori, cujo foco é Bengala no século XIX (hoje em dia dividida entre a Índia e Bangladesh), traz à luz atores liberais pelos quais a história intelectual nunca se interessou: os pequenos proprietários (raiyats) que podiam ser "Lockeanos" sem nunca terem lido Locke.

Esses pequenos proprietários, Sartori mostra, usaram argumentos em defesa da propriedade de tal forma que consolidaram normas liberais relativas ao uso produtivo da terra e ao valor-trabalho. Seria uma adaptação de discursos e práticas europeus para os trópicos, em um país principalmente

\footnotetext{
* Doutorando, History and French Studies, Graduate School of Arts and Sciences, New York University. E-mail: ianwmerkel@gmail.com
} 
agrícola? Para Sartori, a interpretação tradicional não leva em conta os argumentos destes proprietários, fundados que são em uma ecologia prática - em uma região cujas relações sociais são mediadas pelas commodities para exportação. No livro de Sartori se torna evidente que o liberalismo de Bengala - da Índia, de modo geral -, e de muitos países no Hemisfério Sul, não derivaram tanto das ideias do "centro" capitalista: ao contrário, a mercantilização das relações sociais e o triunfo das ideias político-econômicas em terras agrícolas contribuíram para salvar o liberalismo inglês de sua crise do fim do século XIX. Nas palavras de Sartori, “[...] não podemos compreender o liberalismo das elites sem compreender os liberalismos plebeus que o assombraram [...] e nós não compreendemos o liberalismo em qualquer lugar se não entendemos como foi possível que as aspirações políticas dos bengaleses agrários se baseassem nele" (p. 8).

Este livro não é uma história social no sentido clássico do termo. O autor, que contextualiza seus argumentos na teia social, está mais interessado nos argumentos relativos ao trabalho e à propriedade em Bengala que nos arranjos que de fato existiram. Se a troca de commodities e "o processo de longa duração de comercialização e "descomercialização" das relações sociais antes e sob o impacto do capitalismo moderno" (p. 27) são analisados em Liberalism in Empire, cada um dos cinco capítulos tem um lócus que permite compreender mais finamente as relações entre a administração colonial, os grandes proprietários (zemindar), os pequenos proprietários, e as massas camponeses que trabalhavam a terra.

O segundo capítulo é provavelmente o mais forte e convincente. "The Great Rent Case" trata de um processo jurídico que consolidou os direitos de renda dos raiyats relativos aos zemindars; estes últimos beneficiaram-se, até então, na colônia britânica pela exclusividade da renda das terras que eles controlavam, salvo os impostos exigidos pelo governo colonial. Os raiyats, no caso uma espécie de inquilinos, e os seus defensores nos tribunais coloniais mobilizaram o discurso de "custom" (costume) para proteger o valor do trabalho que eles produziam ao trabalharem a terra; o que Sartori mostra é que essa mobilização de uma forma pré-capitalista (costume) não impediu que os mesmos argumentos consolidassem as relações sociais baseadas em normas liberais. Ainda que Sartori aceite, em geral, a afirmação historiográfica de que teria havido uma virada antiliberal na política colonial da Inglaterra no final do século XIX, o autor mostra, todavia, como um retorno ao costume nas colônias podia representar uma intensificação da mercantilização das relações sociais e o fortalecimento dos argumentos político-econômicos, vindos de diversos segmentos da população (p. 38). 
O terceiro capítulo, "Customs and the Crisis of Victorian Liberalism", traz os argumentos sobre o costume, em Bengala, de volta à Inglaterra vitoriana. Com a restrição do acesso à terra e a consolidação de propriedade em poucas mãos na Europa (criando, portanto, uma crise nas condições de possibilidade de uma política liberal, seja em Locke, seja em Mill), a colônia asiática permitiu a emergência de um novo "discurso especificamente liberal de costume" na metrópole (p. 62). O quarto capítulo, "An Agrarian Civil Society?", trata da questão de como a sociedade civil poderia ser imaginada em uma sociedade agrícola. Enquanto os historiadores Partha Chaterjee e Dipesh Chakrabarty, da corrente de estudos subalternos, afirmam que, em resposta à colonização britânica e à falta de poder, os intelectuais indianos voltaram-se à esfera privada (o lar, a família e a cultura), Sartori mostra que o raiyat bengalês era "[...] o campeão da sociedade civil ao invés do seu críti-

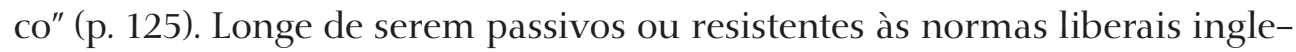
sas, estes pequenos proprietários avançaram a causa da economia política com afirmações lockeanas (de novo, sem fazerem referência a Locke) que dependiam do poder do trabalho na constituição da propriedade (p. 126).

O último capítulo, "Peasant Property and Muslim Freedom", traz os argumentos dos precedentes - todos do período colonial - para o período contemporâneo, como a questão da independência da Índia e de sua partição. Se os primeiros capítulos dependem principalmente de fontes relativas às elites (relatos de processos coloniais, documentos governamentais etc.), este último evidencia um liberalismo "vernacular" - é, no caso de Bangladesh, um liberalismo muçulmano. Ainda que o leitor não especialista certamente vá se perder nos detalhes políticos - a história événementielle, caso se queira - as fontes que Sartori traz à luz, de pensadores populares, fortalecem seu argumento. Ele conseguiu ler as vozes vernáculas por meio dos documentos do período colonial e nos documentos do período mais contemporâneo. Sartori analisa a identificação do agricultor com o Islamismo, produzido por uma moralização dos atributos de ética de trabalho e piedade. Esta moralização serviu para substituir identidades culturais por questões de produção. Infelizmente, Sartori afirma, esta identificação impediu "as trajetórias mais radicais dos discursos liberais de propriedade" (p. 183).

Em Bangladesh, os pequenos proprietários tiveram duas tendências opostas. Por um lado, eles enraizaram a sua propriedade no valor-trabalho, permitindo, assim, o acesso a capital e terra a quem não os detinha anteriormente; por outro lado, eles atenuaram seus argumentos, fixando a propriedade nas mãos de quem já a teve (ou deveria ter), excluindo a possibilidade de um enraizamento político-econômico mais profundo e radical, cujo va- 
lor-trabalho pertenceria seja ao trabalhador, seja à sociedade. Em Bengala, como na Inglaterra e em tantos outros lugares do mundo, a história deste pensamento prático, desta ecologia de afirmações e argumentos sobre a propriedade não é menos "intelectual" por se distanciar dos argumentos originários de Locke. Ao contrário, a análise intelectual focada no pensamento ativo de vários segmentos da população permitirá compreender melhor o enraizamento de ideologias e formas de ser. Andrew Sartori, em Liberalism in Empire, nos oferece algumas pistas de por onde e como começar.

Recebido: 21/05/2016 - Aprovado: 23/09/2016 